\title{
International Law and the Turn to Political Economy
}

DOI:

$10.1017 /$ S0922156518000092

\section{Document Version}

Accepted author manuscript

Link to publication record in Manchester Research Explorer

\section{Citation for published version (APA):}

Haskell, J., \& Rasulov, A. (2018). International Law and the Turn to Political Economy. Leiden Journal of International Law, 31(2), 243-250. https://doi.org/10.1017/S0922156518000092

\section{Published in:}

Leiden Journal of International Law

\section{Citing this paper}

Please note that where the full-text provided on Manchester Research Explorer is the Author Accepted Manuscript or Proof version this may differ from the final Published version. If citing, it is advised that you check and use the publisher's definitive version.

\section{General rights}

Copyright and moral rights for the publications made accessible in the Research Explorer are retained by the authors and/or other copyright owners and it is a condition of accessing publications that users recognise and abide by the legal requirements associated with these rights.

\section{Takedown policy}

If you believe that this document breaches copyright please refer to the University of Manchester's Takedown Procedures [http://man.ac.uk/04Y6Bo] or contact uml.scholarlycommunications@manchester.ac.uk providing relevant details, so we can investigate your claim.

\section{OPEN ACCESS}


Akbar. There has been an interesting shift in international law in recent years. A lot of projects have started to emerge that all seem to proceed from the same basic idea, which is that international lawyers should start paying more attention to questions of political economy, reflecting more consciously about all the different ways in which global economic processes and international legal regimes intersect, and exploring more systematically the relationship between international law and international economic governance. ${ }^{1}$ As someone who works in the area of international economic law, I find this trend very curious.

John. There has, indeed, been a lot of talk lately among international lawyers about political economy. Going to conferences, hearing people talk about their work, you certainly do get the feel that more and more international lawyers are beginning to think that political economy is an important topic for international law to address. But is that enough to say that there has been a turn to political economy?

I am reminded here of that symposium on disciplinary turns that was published six years ago in American Historical Review. ${ }^{2}$ Disciplinary turns are very complex phenomena. However one sets up a map, there is nothing simple or straightforward about them. Is a 'turn' something that takes place in the minds of people or in the institutional realities that surround them? Is it, in other words, a purely theoretical event or is it more an act of disciplinary contestation? One might even say that how we go about answering these questions can itself be considered an act of disciplinary politics.

All of this is by way of saying that I think it is very important for us to be clear just what exactly we have in mind when we talk about disciplinary turns in international law. What does it mean to say that any kind of turn has taken place in international law? It would seem to me that at the very least one has to show there has been a relatively visible shift in the patterns of disciplinary debate. Now, I think it is fairly clear that international lawyers today invoke the language of political economy much more readily than they used to. But does that in itself show or prove anything? Surely, whether or not a turn to political economy has taken place, cannot be resolved by just tracking what language has been trending in international law conversations.

Akbar. I agree. There is an obvious temptation in this kind of situation to want to use some kind of easy metric: the number of times a certain word or phrase has been mentioned in the literature, the number of times a certain concept has been referenced in the title of a conference, and so on. I can see why one may want to go down that route - it gives you the satisfying illusion of certainty - but I think we should resist it at all costs. This way of thinking about the problem takes us in the wrong direction. The intellectual attitude that stands behind this analytical reflex is very problematic. What we are looking at with disciplinary turns is essentially the evolution of a disciplinary sensibility, or, in other words, transformations in the structure of a collective consciousness. This isn't just a case of tracking the number of complaints brought by developing states in the WTO versus the number of complaints brought by developed states in the hope of figuring out on that basis the relative distributive impact of the WTO procedure across time. Things are a lot more fluid and ambiguous when it comes to disciplinary sensibilities.

\footnotetext{
1 See, e.g., M. Fakhri, Sugar and the Making of International Trade Law (2014); G. Baar, 'Reform or Revolution? Polanyian v. Marxian Perspectives on the Regulation of 'the Economic", (2011) 62 Northern Ireland Legal Quarterly 415 (2011); A. Lang, World Trade Law after Neoliberalism (2011); S. Ranganathan, 'Global Commons', (2016) 3:1 EJIL 693; J. Salacuse, 'Of Handcuffs and Signals: Investment Treaties and Capital Flows to Developing Countries', (2017) 58:1 HJIL 127; G. Sarfaty, 'Shining Light on Global Supply Chains', (2015) 56:2 HILF 419; D. Trubek and A. Santos (eds.), The New Law and Economic Development: A Critical Appraisal (2006).
}

2 'Historiographic “Turns” in Critical Perspective', (2012) 117:3 AHR 698. 
How do you evidence what is happening at the level of collective consciousness? Certainly, not just by tracking the number of times a certain concept or idea gets name-checked.

John. I am not sure I like the term sensibility here. But let me then ask this: what exactly does the concept of 'political economy' stand for?

Let me explain. I think most of us have a more or less clear idea what one will usually have in mind when one speaks about, say, 'the linguistic turn' or 'the historical turn'. Both history and linguistics are relatively well-established disciplines that have a long track record of inspiring various inter-disciplinary crossovers. ${ }^{3}$ I am not sure one can put political economy in the same row as history or linguistics, however. It is not really a discipline, at least not the way it seems to be experienced in international law today.

Akbar. No, it is not, and I think that is an important point. Political economy has been historically constructed as a discipline - some may argue it is the parent discipline of all economic sciences - but that is certainly not the way international lawyers today relate to it. The turn to political economy that we are witnessing today in international law is not a turn towards some kind of defined theoretical field, discipline, or methodology.

John. What strikes me here is that political economy in this context often seems to be just a buzzword. It is ubiquitous and yet elusive. To the extent it is not just a moniker providing cover for any type of argumentative trajectory, it mostly seems to be levelled against whatever is perceived at that point to be an expression of mainstream international law thinking.

If we look at the way international lawyers typically mobilise the theme, the move to political economy is basically just a form of critical self-distancing. The particular content through which this self-distancing argument is played is couched in the language of politics and economics but the basic idea behind it is that there is something wrong about the way the mainstream international law scholarship is developing and one needs to articulate an alternative to that. So there is not really anything interdisciplinary or even very programmatic here. There is nothing applied, just a heavy reliance on the Enlightenment ideal that a cognitive revolution leads historical change. And most of the time, the theme of political economy is just used as a standin for some kind of intellectual and political protest against conservative, simplistic ways of imagining global governance, without ever really being spelled out that way. That is at least partly what I think needs to be highlighted about the intellectual reality of this new turn towards international law and political economy.

Akbar. Exactly. The point here is when we talk about disciplinary turns we need to switch the implicit emphasis from the word 'disciplinary' to the word 'turn'. We should move from viewing history, linguistics, anthropology, political economy - you name it - as universal theoretical constants or projections of some sort of pre-existing essences, so that whatever international lawyers may end up reading into the concept of political economy should necessarily be absolutely synonymous or equivalent to what economists or political scientists read into it. That is just not how things work. There isn't one single correct concept of political economy that is valid for all disciplines, and that is perfectly fine.

We can see a parallel here with some of the recent debates surrounding the idea of the historical turn. The history that international lawyers do is very different from the kind of history that professional historians write. It does not take exceptional observational skills to notice that. What is really important here, however, is the historians are getting increasingly vocal in criticising international lawyers on the grounds that they somehow are misunderstanding the nature of the 'historical method'. And I can see where they are coming from. Most of us on some level are probably sympathetic to some of these concerns. But the historians do not, ultimately, have any monopoly over the concept of history or the idea of the historical method,

${ }^{3}$ E. Clark, History, Theory, Text: Historians and the Linguistic Turn (2004). 
and the implied suggestion that legal scholars may need some kind of approval from them to be able to proceed with their own historiographic inquiries is, frankly, preposterous. International lawyers have their own way of doing history. It is neither worse nor better than the history that the professional historians do. The same goes for political economy.

John. We are running two different lines of argument here. They are closely related but they are not the same, and, if only for theoretical purposes, I think we need to carefully distinguish them.

The first argument is that the turn to political economy is not really an exercise in interdisciplinarity but something else entirely. The second argument is that the practice of joining or initiating a disciplinary turn is actually a form of performative activity. It is something like an invocation of a trope, rather than a truth-statement about the world 'out there', about some system of pre-existing disciplinary formations. My interest lies mainly with the latter theme. Speaking about disciplinary turns typically evokes the notion of some quasi-territorialised field of interdisciplinary linkages: linguistics is here, international law is there, history and anthropology way over to that side, and so on. I find this kind of mental imagery deeply misleading. It misrepresents how blurry and unstable the 'external' boundaries between different fields are, but it also obscures the enormous diversity of epistemologies and traditions we can find within each of these fields.

Akbar. Now that you put it like that, I agree, there are two fairly distinct lines of argument here. In my case, it is the first one that I find more interesting. When they perform their turn to political economy today, international lawyers do not treat political economy as a distinct discipline. But it is certainly not impossible to think of it in that way. It has been done before, and there is definitely a lot that international lawyers can learn from this history.

To put it in a slightly telegraphic fashion, as a disciplinary project, political economy has always had a rather peculiar theoretical profile. Its main themes, aesthetically and ideologically, have been the concept of social physics - the assumption that there exist 'iron laws' of social life that work in a way similar to Newton's law of gravity - and the idea of what you might call finding the public within the private.

A large part of it goes back to its origins in the early Enlightenment period, when scholars such as Antoine de Montchretien - who may very well have been the first author to use the term political economy in the title of his book - started converging around the theory that one of the main functions of the government was not just to bring peace and to protect l'ordre public, but to encourage economic activity and to promote free trade. As Ellen Wood notes, Montchretien's basic presumption here was that the government essentially performs the same function vis-à-vis the rest of the society as the pater familias does vis-à-vis the members of his household: its main task is to 'rule benevolently, like the father with an eye to the well-being, harmony, and prosperity of [all]'. The crucial difference here, of course, is that most people in the wider society are ultimately motivated more by narrow self-interest than any kind of familial sentiment. But that, he remarks immediately, is not in itself a problem, since 'selfish passions and the appetite for gain, far from threatening the common good, can [actually become] its foundation'. 5

John. It is this last bit that I think provides us with the theoretical crux of political economy: the open acknowledgement that private vice can give rise to public virtue. This is the same logic that we see today even among across the most critically self-aware segments of the international law literature: the notion of resuscitating the dark sides of the rule of law, the idea that the universal can be build from within the particular. To my mind, all this evokes a deeply Christian motif, and in a distinctly American register at that. It is the logic of the 'Field of Dreams', of

\footnotetext{
${ }^{4}$ E.M. Wood, Liberty and Property (2012), 167.

${ }^{5}$ Ibid., at 168 .
} 
Noah's Ark, the notion that if you follow your particular dream, it will somehow result in the greatest good possible for all.

Akbar. I agree that the idea that private vice can turn into public virtue is a key conceptual theme. It is the tipping point, aesthetically and ideologically. Because once you have accepted it, it only becomes a matter of time before your next question becomes: how does this mechanism work? How can all these 'selfish passions' and 'private vices' be best harnessed and controlled, how can they be put to use, in other words, as opposed to, say, how can they be best repressed, educated-away, or resisted? Hence, incidentally, the typical emphasis in the political economy tradition on the ideas of management-encouragement-promotion, as opposed to, say, commandprescription-sanction (as in Hobbes or Austin), and hence also the traditional concept of political economy as the discipline that studies the public management of private rationalities.

In one way or another, you can trace this vision of political economy all the way from Bernard Mandeville and the Scottish Enlightenment, down to Karl Polanyi, J. K. Galbraith, and Douglass North. Marx adds a few unusual wrinkles, but even he under certain conditions can be added to this broad tradition. The important point here, however, is that this concept of political economy - the idea of the public management of private rationalities, the search for the iron laws of social physics - has really nothing to do with what political economy means to international lawyers.

John. That is true. The concept of political economy that international lawyers implicitly use is a lot more diffuse and unfocused than that. If you ask international lawyers what they mean by political economy today, I think what you are going to find is that for most of them it simply stands for some basic idea that economic structures and political power are fused together; that economic processes are not really autonomous or self-sustaining; that they are, in fact, heavily infused with political struggles and conflict; and that international law is a more or less important platform and instrument that can be used in these struggles.

This is not to say, of course, that an international lawyer would not be able to define political economy in any other way. But if you look at the way the concept of political economy has been used in the actual practice of the contemporary international law discourse, it is very unlikely that you are going to see anything more specific than this very basic idea that politics and economics are not fully separate from one another.

Akbar. And this, of course, goes back to our earlier point that we cannot understand the turn to political economy as an exercise in inter-disciplinarity. Which raises the question: how should we then understand this idea of a 'turn to political economy'?

John. Right, and if 'political economy' is not just a topic that you write on, and it is not a separate discipline that you cross-over into, what is it that the 'turn to political economy' actually means? And to ask this question again intimates a reflective posture, about international law as an epistemic community, and that word again, 'sensibility'. Are you using sensibility in the same way, for instance, that Martti Koskenniemi does at the start of The Gentle Civilizer of Nations?'

Akbar. Yes, although I prefer to think of it in slightly more structuralist terms, as a kind of a langue. Every discipline, international law included, has a certain sensibility at its core. This sensibility is organised around a certain langue-like structure. I borrow this idea from Duncan Kennedy's theory of legal consciousness: a sensibility, as I understand it, is both an organic cultural construct and a structural, semiotically functioning order. ${ }^{7}$ A disciplinary turn is an event in the history of disciplinary sensibility.

${ }^{6}$ M. Koskenniemi, The Gentle Civilizer of Nations: The Rise and Fall of International Law 1870-1960 (2002), 2.

${ }^{7}$ For further discussion, see D. Kennedy, Legal Reasoning: Collected Essays (2008). 
John. I am not sure I find the concept of sensibility very helpful. I think it is too woolly and it also has the unfortunate tendency to encourage precisely the kind of homogenising assumptions about disciplinary fields that we should resist.

Let me suggest, therefore, that we take a slightly different angle. Earlier I mentioned that I am interested in exploring the practice of participating in disciplinary turns as a form of performative activity and an act of disciplinary politics. And there is definitely a certain kind of legitimation/de-legitimation dynamics that immediately sets in the moment we invoke the narrative of turns, which then results in all kinds of intellectual and resource-redistribution effects within the discipline's broader social field. There is no doubt about that. Having said that, I think it is also important here to recognise that the language of disciplinary turns is not just a device that can be used whenever it suits us.

Even if the narrative of turns performs all kinds of intellectual and ideological effects, there will usually be a certain basic reality behind it. It may be difficult to capture it or to reduce to any set of measurable metrics, but it is still there. We can't just start talking about a 'turn', or a shift in 'sensibility' for that matter, just because we feel like it.

Now, in this case, this reality, in my view, has a very clearly identifiable historical horizon. A lot of this new scholarship that we are talking about has been produced by scholars who 'came of age' professionally in the last ten or fifteen years.

Akbar. Yes, I suppose that what we have with every disciplinary turn, in addition to everything else, is also a case of inter-generational supersession.

John. Absolutely. And even leaving aside the question of inter-generational conflicts for the moment, I think looking at the idea of the turn to political economy historically helps us highlight a number of important aspects about the problem.

The difficulty with going about things in this way, of course, is that we not only need to be able to connect a variety of events in the world 'out there', but we also have to navigate our way through the sociology of our profession, which introduces stakes that may feel more personal.

Akbar. I am intrigued by the connection you imply between the timing of this turn to political economy and its deeper content. If we do take seriously this concept that most of this new scholarship is produced by scholars who came of age professionally in the last ten to fifteen years, what I am wondering about is what was it that pushed them all to start moving in that direction together? International law is not a completely autonomous system: the way in which the discipline evolves does, in the end, tend to be influenced by real-world events. So what do you think must have been the trigger event here? Did the 2003 invasion of Iraq or the 2008 global financial crisis have anything to do with it?

John. I am not sure about the former, but the latter definitely seems to be an important contributing cause. Without getting into the sociological gristle of our current disciplinary milieu, I think if we factor the 2008 crisis into the equation it can explain a lot, especially why this intellectual shift happens when it does and why it is characterised by such a prevalence of concern and the use of the language of 'political economy'.

In other ways, though, singling out the crisis can cause us to ignore a host of other complimentary trajectories, or at least contributory events that helped set the conditions for political economy to come to the fore. The boogeyman of 'neoliberalism', for instance, started circulating decades before, at least in other disciplines, and 'critical' international lawyers have been fighting a rearguard effort against 'law and economics' for what feels like a long time. ${ }^{8}$ To

\footnotetext{
${ }^{8}$ See P. Mirowski, 'The Political Movement that Dared not Speak its own Name: The Neoliberal Thought Collective Under Erasure', (2014) Institute For New Economic Thinking Working Paper No. 23.
} 
some extent, in the past this fight seems to have drawn inspiration more from postcolonial studies and European (post)structuralist writings, usually teaming up with what we might think of liberal democratic political movements. These inspirations are still in the mix but perhaps less pronounced when we speak about political economy today. But what all of these movements, at their core, traditionally have been concerned about - and still often are - is what I tend to think of as the visceral scale of inequality locally and abroad.

What has been different about this new generation of international law scholars that turned to the themes of political economy, it seems to me, is the confluence of the intellectual and ideological legacies of these traditions and the historical experience of the 2008 global financial crisis. This sense of inequality is now more commonly associated with the idea of capitalism - the whole setup of capitalist mode of social intercourse itself - especially whether it is sustainable and what other alternative systems could potentially take its place. To speak about capitalism is something that wasn't nearly as prevalent fifteen years ago among international law scholars.

Akbar. So, the turn to political economy in your reading is basically a new generation of international law scholars awakening to the visceral realities of capitalism?

John. Yes, and them doing so as international law scholars, rather than, say, as 'just' lawyers or as concerned citizens. And not that you can necessarily wake up, but it seems to enable different ways to think about things again.

Akbar. Is it any specific idea of capitalism that they suddenly experience? Marx's concept of capitalism, for instance, is quite different from Polanyi's.

John. It is not necessarily a Marxist concept of capitalism that we are dealing with here.

There are several different traditions of thinking about capitalism that we can detect in the recent international law scholarship. Broadly speaking, they all converge around the idea that every socio-economic situation in which international law is implicated is the result, ultimately, of political decisions made in an unequal fashion and bearing unequal distributive impact, and the general goal for international law is to help those who strive for a more deliberate and egalitarian regime of governance.

Take money, for instance; once you realise that money does not naturally arise out of exchange but is a legally constituted devise generated and backed up with force by a corporeal political power - namely, the state - you suddenly have your policy options liberated in a way that is unimaginable, or at least decried, by what we might call more dominant class actors, because it makes naked the contingent nature of inequality in society. ${ }^{9}$ This is not to suggest you can just appropriate the means of production and everything else follows suit. The whole point of Marxist dialectics would indicate that since economic phenomena only ever exist in a distinct historical configuration, which is integrated with every other aspect of society, any one institutional terrain or sub-terrain - economic, social, political - is inherently tethered to the disparate totality of all other institutional dynamics. So it resists any easy prescription. But it does point to one seminal place where liberal and Marxist conceptions of capitalism diverge, that being whether progressive change can occur without a fundamental recalibration of the modes of the economy.

Akbar. And there is, of course, more than one Marxist conception of capitalism and international law's place in it. Just to use the most obvious example, China Mieville and B. S. Chimni do not just give us very different diagnoses, they also give us completely different

\footnotetext{
${ }^{9}$ See C. Desan, Making Money: Coin, Currency, and the Coming of Capitalism (2015); R. Kreitner, 'Toward a political economy of money', in U. Mattei and J. Haskell (eds.), Research Handbook on Political Economy and Law (2014), 2.
} 
prescriptions: one essentially ends up advocating a species of (righteous) legal nihilism, ${ }^{10}$ the other expounds the virtues of a 'radicalism with rules'. ${ }^{11}$

John: But there is something more than that here. In the second appendix to The Nomos of the Earth, Carl Schmitt argues that the fundamental problem with liberalism and its 'doctrine of freedom... [the] queen of all freedoms, consumption' is that it ignores that every human ordering is always premised on a 'primitive law' of 'appropriation-distribution-production'.12 Liberalism in all its forms holds that progress occurs via freeing productive powers to increase production to increase mass consumer well-being, which means there is no need for any consideration of appropriation.

In other words, appropriation just drops out of the liberal imagination, which Schmitt calls the 'lie of production... the Beehive fomula, of things governing themselves'. ${ }^{13}$ He takes this into dark territory by naming the Fuhrer as the inescapable 'great appropriator' and lamenting the 'last great heroic act' of Europe to be the conquest of North America - and I think this is the critique usually levelled at left-oriented positions, that if they get their way it will lead to totalitarian nightmare - but there seems to be a truth here that doesn't necessitate such insidious conclusions. What seems important to me is the observation that any human-made system is built on a framework that begins with a logic of appropriation, from which follows particular designs of distribution and production, and you cannot fundamentally shape the world anew without revisiting this initial appropriation logic. And there are quite a few interesting parallels here with some Marxist scholarship too, not least the idea of primitive accumulation. ${ }^{14}$

Akbar. It is interesting that you put it like that. Because if you look at the articles that follow, each of the authors intimates many of the same concerns, engaged in different forms of a struggle concerning appropriation.

John: I agree, to varying degrees they are speaking in chorus. Channeled geographers and international relations literature, Rajkovic breaks down the territorial prejudices that continue to carry weight in international law. And I don't think it is by chance that in many respects it was from international relations that international political economy re-entered governance scholarship and attracted scholarly traditions that worked against 'mainstream' state-centric concepts. Behind Rajkovic's spatial re-imagination of jurisdiction is the spectre of a rapidly more noticeable capitalism, in a state of what feels like constant creative destruction. The contributions by Saab and Moudud also work around political economy and law traditions. Moudud writes as an economist, and marries a specific brand of political economy, Modern Money Theory, with the critical legal studies tradition, to think out how these intellectual traditions help us better understand the nature of money and the role of law and finance in shaping global governance. ${ }^{15}$ For Saab, the focus is on food regime to show how combining lessons from sociology and close readings of international legal texts can help denaturalise

${ }^{10}$ C. Mieville, Between Equal Rights (2005).

${ }^{11}$ B. S. Chimni, International Law and World Order (2017).

${ }^{12}$ C. Schmitt, 'Appropriation/Distribution/Production: Toward a Proper Formulation of Basic Questions of any Social and Economic Order’, (1993) 95 Telos 52, 60-61.

${ }^{13}$ C. Schmitt, Nomos of the Earth in the International Law of the Jus Publicum Europium (2003), 347.

${ }^{14}$ For background, see M. Neocleous, 'International Law as Primitive Accumulation', (2012) 23 EJIL 941.

15 For a seminal text in modern money theory, see R. Wray, Modern Money Theory: A Primer on Macroeconomics for Sovereign Monetary Systems (2012). There is a growing community and literature centred around critical legal theory with an economic orientation, especially on the East Coast of the US, with concentrations at universities such as Cornell Law School and networks such as the Association for the Promotion of Political Economy and the Law (APPEAL) and the Institute for Global Law and Policy (IGLP). 
questions of scarcity and hunger. In broad strokes, you could say the texts speak from economics, international law and international relations, and address the pillars of political economy - commodities (food), money (finance), and property (territorial boundaries) - and to varying degrees, all speak to the common question of capitalism. There is nothing programmatic, but that seems quite in keeping with the sensibility of political economy in international law scholarship, which I imagine is what makes it such an exciting moment. 